\title{
Heterosis and Inbreeding Depression in $\mathrm{F}_{2}$ Populations of Upland Cotton (Gossypium hirsutum L.)
}

\author{
Bilal Ahmed Khan', Naqib Ullah Khan', Mehboob Ahmed', Mazhar Iqbal', \\ Ihsan Ullah', Maria Saleem', Isma Khurshid', Aneela Kanwal1 \\ ${ }^{1}$ Hazara Agriculture Research Station, Abbottabad, Pakistan \\ ${ }^{2}$ University of Agriculture Peshawar, Peshawar, Pakistan \\ Email: bilalahmed_pbg@yahoo.com,nukmarwat@yahoo.com, mehboob05pbg@yahoo.co.uk, mazhar.kts@gmail.com, \\ ihsanullah@yahoo.com, mariasaleemawan@gmail.com, ismakhurshid83@gmail.com, aneelakanwal389@gmail.com
}

How to cite this paper: Khan, B.A., Khan, N.U., Ahmed, M., Iqbal, M., Ullah, I., Saleem, M., Khurshid, I. and Kanwal, A. (2017) Heterosis and Inbreeding Depression in $\mathrm{F}_{2}$ Populations of Upland Cotton (Gossypium hirsutum L.). Agricultural Sciences, 8, 1283-1295.

https://doi.org/10.4236/as.2017.811093

Received: November 28, 2016 Accepted: November 14, 2017 Published: November 17, 2017

Copyright $\odot 2017$ by authors and Scientific Research Publishing Inc. This work is licensed under the Creative Commons Attribution International License (CC BY 4.0).

http://creativecommons.org/licenses/by/4.0/

\section{c) (i) Open Access}

\begin{abstract}
Hybrid cotton production through exploitation of heterosis is the only way for having vertical improvement and betterment in seed cotton yield which has been stagnated in the recent years. The current study was conducted to evaluate the performance of $\mathrm{F}_{2}$ population for studying mean performance, heterotic effects and inbreeding depression in upland cotton for polygenic traits. Parental genotypes and their $\mathrm{F}_{2} \mathrm{~s}$ were sown at Khyber Pakhtunkhwa Agricultural University, Peshawar during 2010, manually. All the traits revealed highly significant $(p \leq 0.01)$ variations for both parents and their $\mathrm{F}_{2}$ hybrids. Mean performance for parents and their $\mathrm{F}_{2}$ hybrids is: (5.26 to $7.12 \& 4.43$ to 6.60) seeds locule ${ }^{-1}$, (21.10 to $28.03 \& 20.40$ to 28.50$)$ seed boll ${ }^{-1}$, (32.20 to $34.80 \& 32.22$ to 35.05 ) lint $\%$ and (62.87 to $85.47 \& 45.94$ to 92.04 ) seed cotton yield plant ${ }^{-1}$, respectively. Heterotic effects found over mid parent and better parent were: $66.66 \%$ \& $46.66 \%$ (seeds locule ${ }^{-1}$ ), $60 \%$ \& 30\% (seed boll ${ }^{-1}$ ), $43.33 \% \& 30 \%$ (lint $\%$ ) and $36.66 \%$ \& $16.66 \%$ (seed cotton yield plant ${ }^{-1}$ ), respectively. For the parameters: seeds locule ${ }^{-1}(11 \& 10)$, seeds boll ${ }^{-1}(2 \& 1)$ and seed cotton yield plant ${ }^{-1}$ ( $3 \& 1$ ) showed positive highly significant heterosis for both mid and better parent, respectively while lint\% did not reveal any positive significant heterosis. $\mathrm{F}_{2}$ populations i.e. CIM- $499 \times \mathrm{CIM}-554$ and CIM-554 $\times$ CIM-499 revealed highly significant heterotic effects over mid and better parent for all the traits except lint \% while CIM-554 $\times$ CIM-707 showed highly significant heterotic effects for seeds locule $^{-1}$ and seed cotton yield palnt $^{-1}$. Positive economic heterotic effects were also exhibited by more than $50 \%$ of the $\mathrm{F}_{2}$ population i.e., $76.66 \%$ for seed locule ${ }^{-1}, 50 \%$ for seeds boll ${ }^{-1}$, $3.33 \%$ for lint $\%$ and $20 \%$ for seed cotton yield plant ${ }^{-1}$, respectively. By comparing $\mathrm{F}_{2}$ mean values with $\mathrm{F}_{1}$ s, only lint $\%$ showed $(0.00 \%$ to $15.55 \%)$ maxi-
\end{abstract}


mum inbreeding depression while negligible amount of inbreeding depression was observed for the remaining traits. However, negative inbreeding depression was revealed by majority of the $\mathrm{F}_{2}$ population like $96.66 \%$ (seeds locule $^{-1}$ \& seeds boll ${ }^{-1}$ ), 60\% (lint $\%$ ) and 90\% (seed cotton yield ${ }^{-1}$ ), respectively meant $\mathrm{F}_{2}$ population has shown more stability even after segregation and have exceeded the check cultivars and better parents in performance.

\section{Keywords}

Heterosis, Inbreeding Depression, Lint, $\mathrm{F}_{2}$

\section{Introduction}

Cotton (Gossypium hirsutum L.) is a major cash crop, often cross-pollinated, long day plant belonging to the family Malvacae. It is a sixth largest source of vegetable oil in the world and can boost up the economy of any country by producing edible oil for human consumption, feed (seed cake) for animals and local consumption in textile industries. Worldwide, most common cultivated species of cotton is Gossypium hirsutum L., a tetraploid, also called as upland cotton and provides $90 \%$ fiber production while Gossypium barbadense called as Egyptian cotton produces only $3 \%$ fiber. These both species are also known as new world cotton [1].

Heterosis (over better parent) is a best source for improvement of $F_{1}$ and $F_{2}$ hybrids for production. It has ability which can lead breeders for commercial utilization of valuable hybrid combinations in breeding program. It can also play a vital role for selection of potential parents with desired vigor, maternal effects and genetic variance. Hybrid cotton has successfully attracted the concentration of cotton breeders for commercial utilization of hybrid progenies [2]. However, hybrid cotton has been produced successfully on primary basis since 1960s in countries like China and India due to availability of cheaper labor.

Inbreeding depression is also related to high heterosis in $\mathrm{F}_{1}$ hybrids and has to search for moderate type of heterosis which has some stability to have less inbreeding depression at $\mathrm{F}_{2}$ level [3]. Allelic and non-allelic interactions of genes in presence of specific environmental effects will lead us to successful heterosis results. Superiority of hybrids over commercial cultivars and genotypes is known as useful heterosis [4]. It is a well-known fact that without proper combination of parents, heterosis does not occur. Heterosis can be used for enhancement of cotton production by exploitation of heterozygosity and to get such cotton hybrids which are superior to best parents. The comparison of performance of the best hybrids with standard cultivars will result in determination of economic heterosis.

The $\mathrm{F}_{2}$ lines revealed larger range of adaptation regarding to their parents and $\mathrm{F}_{1}$ hybrids due to presence of genetic variation and larger heterogenity [5] [6]. 
$\mathrm{F}_{2} \mathrm{~s}$ can produce better combinations of fiber quality and yield than their parents and $\mathrm{F}_{2} \mathrm{~s}$ yield was highly correlated with $\mathrm{F}_{1} \mathrm{~s}$ and parental lines. It is expected that $\mathrm{F}_{2}$ populations express only $50 \%$ of the economic heterosis shown by $\mathrm{F}_{1}$ hybrids, and even less when heterosis is defined in terms of the higher yielding parent. Nonetheless, $\mathrm{F}_{2}$ lines with lower inbreeding depression in yield and superior performance than well-adapted cultivars have been found. The existence of such lines lends credibility to the use of $\mathrm{F}_{2} \mathrm{~s}$ in hybrid cotton production. Previous findings are also of view about the $\mathrm{F}_{2}$ hybrids heterosis in cotton [7]. On the other hand, a group of physical properties can play a vital role in determination of textile use and economic value of cotton. The cotton hybrid can be produced through heterobeltiosis by crossing two cotton cultivars to enhance seed production in combination with better fiber quality [8].

A successful cotton breeding program depends upon the choice and use of best parental lines for crossing and selection of favorable gene combinations. Improvements in cotton yields can be made by applying dependable tools to cotton breeders regarding to heterotic studies and inbreeding depression. For enhancement of production per unit area by proper availability of environment, identification and selection of genotypes with best genetic potential is a regular requirement. In view of economic importance of hybrid cotton cultivation and importance of selected hybrids in segregating generations, the current research was undertaken to study the genetic potential, heterotic effects and inbreeding depression for yield related traits in $6 \times 6 \mathrm{~F}_{2}$ diallel populations of upland cotton.

\section{Materials and Methods}

Genetic material: Breeding material used during the study of genetic potential, heterotic effects and inbreeding depression for yield related traits in $6 \times 6 \mathrm{~F}_{2}$ populations of upland cotton were consisted of six different Gossypium hirsutum L. genotypes i.e. CIM-446, CIM-496, CIM-499, CIM-506, CIM-554 and CIM-707 (having broad genetic base and varied by pedigree, date of release, seed cotton yield and fiber quality traits) and their $30 \mathrm{~F}_{2}$ cross combinations in a complete diallel fashion. Some of the characteristics of used varieties/genotypes during the study have been mentioned below.

Experimental design and field procedures: The mean performance, heterosis

\begin{tabular}{cccccccc}
\hline \multirow{2}{*}{ S.No } & Variety & Year of & Ginning & \multicolumn{2}{c}{ Staple Length } & Micronaire & $\begin{array}{c}\text { Fibre Strength } \\
\text { (tppsi) }\end{array}$ \\
& & Release & Out-Turn (\%) & Inch & Mm & & 97.4 \\
\hline 1 & CIM-446 & 1998 & 36.2 & $1-1 / 16$ & 27.0 & 4.7 & 93.5 \\
2 & CIM-496 & 2005 & 41.1 & $1-5 / 32$ & 29.7 & 4.6 & 97.3 \\
3 & CIM-499 & 2003 & 40.2 & $1-5 / 32$ & 29.6 & 4.4 & 98.9 \\
4 & CIM-506 & 2004 & 38.5 & $1-1 / 8$ & 28.7 & 4.5 & 96.8 \\
5 & CIM-554 & 2009 & 41.5 & $1-1 / 8$ & 28.5 & 4.7 & 97.5 \\
6 & CIM-707 & 2004 & 38.1 & $1-1 / 4$ & 32.5 & 4.2 & \\
\hline
\end{tabular}


and inbreeding depression in parental genotypes and their $F_{2}$ populations of upland cotton for polygenic traits were conducted at Khyber Pakhtunkhwa Agricultural University, Peshawar during 2010. The hand sown method was used for parental genotypes and their $\mathrm{F}_{2} \mathrm{~s}$ in a randomized complete block (RCB) design with three replications. Each treatment was consisted of two rows having four meter length with $30 \mathrm{~cm}$ plant to plant and $75 \mathrm{~cm}$ row to row distance. All the recommended cultural practices and inputs were applied for all the entries from time of sowing till the harvesting including fertilizer, hoeing, irrigation and pest control and the crop was grown in uniform conditions to reduce the environmental variability. Boll picking was done for two times on single plant basis and ginning was made with eight saw-gins.

Statistical analysis: Data for all the variables were analyzed through analysis of variance (ANOVA) [9]. After getting the significant differences, the means were further compared and separated with least significant difference (LSD) test.

Heterosis: The $F_{2}$ heterosis over mid parents was calculated in terms of percent increase $(+)$ or decrease $(-)$ of $\mathrm{F}_{2}$ hybrids against its mid parent values according to the following formula [10].

$$
\text { Heterosis } \%=\frac{\overline{F_{2}}-\overline{M P}}{\overline{M P}} \times 100
$$

The $F_{2}$ heterobeltiosis (heterosis over better parents) was formulated in terms of percent increase/decrease of $F_{2}$ hybrid over its better parent according to [11] by using following formula.

$$
\text { Heterobeltiosis } \%=\frac{\bar{F}_{2}-\overline{B P}}{\overline{B P}} \times 100
$$

The " $t$ " test was used to determine whether the mid and better parents $\mathrm{F}_{2}$ heterosis was significant or not. The " $t$ " values were computed by using the following formula according to [12].

$$
t=\frac{\bar{F}_{2 i j}-\overline{M P}_{i j} / \overline{B P}_{i j}}{\sqrt{\frac{3}{8}(E M S)}}
$$

where;

$$
\begin{aligned}
& \bar{F}_{2 i j}=\text { Mean of the } i j^{\text {th }} \bar{F} \text { cross. } \\
& \overline{M P}_{i j}=\text { Mid parent value for the } i j^{\text {th }} \text { cross. } \\
& \overline{B P}_{i j}=\text { Better parent value for the } i j^{\text {th }} \text { cross. } \\
& E M S=\text { Error mean square. }
\end{aligned}
$$

For assessment of economic heterosis, the cultivar CIM-473 was used as check cultivar and was also grown with other cultivars but was not included in $6 \times 6$ diallel hybrids. The check cultivar was compared with mean values of other parental cultivars and $\mathrm{F}_{2}$ hybrids and economic heterosis was formulated.

Inbreeding depression: Inbreeding depression in $F_{2}$ hybrids was calculated as percent decrease of $F_{2}$ hybrids when compared with $F_{1}$ hybrid means as outlined 
by [13].

$$
\text { Inbreeding Depression } \%=\frac{F_{2}-F_{1}}{F_{1}} \times 100
$$

\section{Results and Discussion}

Regarding analysis of variance, the mean values for thirty six cotton genotypes including six parents and their $30 \mathrm{~F}_{2}$ hybrids revealed highly significant differences $(p \leq 0.01)$ for seeds per locule, seeds per bolls, lint $\%$ and seed cotton yield per plant, respectively (Table 1 ). The traits wise results about genetic potential, heterosis over mid and better parents and inbreeding depression in $\mathrm{F}_{2}$ populations in light of previous review are discussed as follows.

Seeds per locule: Seeds per locule varied from 5.26 (CIM-554) to 7.12 (CIM-446) among parents and 4.43 (CIM-506 $\times$ CIM-496) to $6.60($ CIM-496 $\times$ CIM-499 \& CIM-554 $\times$ CIM-707) in $\mathrm{F}_{2}$ population (Table 2). Seeds per locule play a vital role in determining of seed cotton yield and is highly associated with production of boll number means high boll number will lead to more number of locules and ultimately produce more seed cotton yield, before ginning. Out of 30 $\mathrm{F}_{2}$ cross combinations, 20 showed positive value of mid parents heterosis ranged from $0.00 \%$ (CIM-446 $\times$ CIM-554) to $22.22 \%$ (CIM-554 $\times$ CIM-707), while $14 \mathrm{~F}_{2}$ hybrids revealed superior performances over their parents ranged from $0.17 \%$ $\left(\right.$ CIM-496 $\times$ CIM-707) to $19.13 \%\left(\right.$ CIM-554 $\times$ CIM-707). Remaining, $\mathrm{F}_{2}$ population showed negative heterotic performance for mid parent and better parent. Collectively, $22 \mathrm{~F}_{2}$ hybrids showed significant heterosis for mid parent and better parent, respectively [14] [15] [16] [17]. Moreover, $23 \mathrm{~F}_{2}$ hybrids revealed 76.66\% economic heterosis ranged from $1.99 \%(\mathrm{CIM}-554 \times \mathrm{CIM}-506)$ to $19.13 \%$ (CIM-554 $\times$ CIM-707). It is expected that $\mathrm{F}_{2}$ populations express $50 \%$ of the economic heterosis shown by $\mathrm{F}_{1}$ hybrids, and even less when heterosis is defined in terms of the higher yielding parent. Overall, $66.66 \%, 46.66 \%$ and $76.66 \%$ heterotic performance was recorded for mid parent, better parent and for economic heterosis, respectively (Table 3 ). In case of inbreeding depression, $F_{2}$ population performed better and showed negative inbreeding depression except the cross CIM-554 $\times$ CIM-499 which only performed (0.00\%) positively means $\mathrm{F}_{2}$ population have increased the number of seeds per locule which is desirable

Table 1. Mean squares and CV\% of various Morpho-yield traits of upland cotton.

\begin{tabular}{ccc}
\hline Parameters & Mean squares & CV \% \\
\hline Seeds locule $^{-1}$ & $0.84^{* *}$ & 4.12 \\
Seeds boll $^{-1}$ & $4.99^{* *}$ & 10.82 \\
Lint \% & $1.79^{* *}$ & 2.81 \\
Seed cotton yield plant & & 8.83 \\
\hline
\end{tabular}

**, Significant at $p \leq 0.01$. 
Table 2. Mean performance of parental cultivars and $\mathrm{F}_{2}$ s for Morpho-yield traits of upland cotton.

\begin{tabular}{|c|c|c|c|c|}
\hline Parents and $F_{2}$ Populations & Seeds locule ${ }^{-1}$ & Seeds boll ${ }^{-1}$ & Lint $\%$ & Seed cotton yield plant ${ }^{-1}(\mathrm{~g})$ \\
\hline CIM-446 & 7.12 & 28.03 & 32.27 & 62.87 \\
\hline CIM-496 & 6.04 & 25.97 & 33.70 & 85.47 \\
\hline CIM-499 & 5.46 & 22.13 & 34.07 & 75.86 \\
\hline CIM-506 & 5.49 & 22.20 & 34.80 & 84.26 \\
\hline CIM-554 & 5.26 & 21.10 & 33.12 & 55.74 \\
\hline CIM-707 & 5.54 & 24.03 & 32.20 & 73.09 \\
\hline CIM-446 × CIM-496 & 5.82 & 23.07 & 32.10 & 74.56 \\
\hline CIM-446 × CIM-499 & 5.71 & 23.43 & 32.77 & 45.94 \\
\hline CIM-446 × CIM-506 & 6.37 & 27.23 & 32.52 & 70.11 \\
\hline CIM-446 × CIM-554 & 6.19 & 25.27 & 33.05 & 72.56 \\
\hline CIM-446 × CIM-707 & 5.35 & 22.97 & 32.72 & 72.95 \\
\hline CIM-496 × CIM-446 & 6.20 & 26.53 & 35.05 & 80.99 \\
\hline CIM-496 × CIM-499 & 6.60 & 27.20 & 33.75 & 70.90 \\
\hline CIM-496 × CIM-506 & 4.89 & 20.40 & 34.08 & 61.57 \\
\hline CIM-496 × CIM-554 & 5.81 & 25.73 & 33.96 & 76.89 \\
\hline CIM-496 × CIM-707 & 6.05 & 24.20 & 32.71 & 52.97 \\
\hline CIM-499 × CIM-446 & 5.30 & 23.93 & 33.54 & 60.32 \\
\hline CIM-499 × CIM-496 & 5.37 & 24.07 & 33.54 & 59.89 \\
\hline CIM-499 × CIM-506 & 6.50 & 25.07 & 33.55 & 70.29 \\
\hline CIM-499 × CIM-554 & 6.19 & 26.07 & 34.59 & 73.79 \\
\hline CIM-499 × CIM-707 & 6.52 & 25.33 & 34.54 & 73.75 \\
\hline CIM-506 × CIM-446 & 6.53 & 25.53 & 32.22 & 61.76 \\
\hline CIM-506 × CIM-496 & 4.43 & 20.80 & 34.36 & 92.04 \\
\hline CIM-506 × CIM-499 & 5.48 & 21.77 & 33.12 & 73.13 \\
\hline CIM-506 × CIM-554 & 5.85 & 22.47 & 34.30 & 59.50 \\
\hline CIM-506 × CIM-707 & 6.52 & 28.50 & 33.85 & 75.25 \\
\hline CIM-554 × CIM-446 & 6.42 & 22.10 & 34.52 & 53.77 \\
\hline CIM-554 × CIM-496 & 5.52 & 21.67 & 34.13 & 60.91 \\
\hline CIM-554 × CIM-499 & 6.17 & 25.83 & 33.69 & 86.01 \\
\hline CIM-554 × CIM-506 & 5.65 & 24.80 & 33.59 & 74.17 \\
\hline CIM-554 × CIM-707 & 6.60 & 23.60 & 34.13 & 77.27 \\
\hline CIM-707 × CIM-446 & 6.15 & 22.23 & 33.35 & 59.89 \\
\hline CIM-707 × CIM-496 & 6.06 & 25.00 & 32.86 & 67.94 \\
\hline CIM-707 × CIM-499 & 5.98 & 25.23 & 33.44 & 77.55 \\
\hline CIM-707 × CIM-506 & 6.35 & 23.33 & 33.44 & 70.81 \\
\hline CIM-707 × CIM-554 & 6.09 & 23.53 & 33.24 & 53.55 \\
\hline $\mathrm{LSD}_{0.05}$ & 0.3985 & 4.356 & 1.210 & 7.437 \\
\hline
\end{tabular}


Table 3. Heterosis (MP, BP \& Eco.) and Inbreeding Depression for Seeds locule ${ }^{-1}$ and Seeds boll ${ }^{-1}$ in $\mathrm{F}_{2}$ s of upland cotton.

\begin{tabular}{|c|c|c|c|c|c|c|c|c|}
\hline \multirow{2}{*}{$\mathrm{F}_{2}$ Populations } & \multicolumn{4}{|c|}{ Seeds per Locules } & \multicolumn{4}{|c|}{ Seeds per boll } \\
\hline & MP (\%) & BP (\%) & Ec. Het (\%) & Inb. Dep. (\%) & MP (\%) & BP (\%) & Ec. Het (\%) & Inb. Dep. (\%) \\
\hline CIM-446 × CIM-496 & -11.55 & -18.26 & 5.05 & -16.74 & -14.56 & -17.70 & -4.27 & -24.73 \\
\hline CIM-446 × CIM-499 & -9.22 & -19.80 & 3.07 & -20.91 & -6.58 & -16.41 & -2.78 & -24.39 \\
\hline CIM-446 × CIM-506 & 1.11 & -10.53 & 14.98 & -11.65 & 8.44 & -2.85 & 12.99 & -14.53 \\
\hline CIM- 446 × CIM-554 & 0.00 & -13.06 & 11.73 & -21.74 & 2.89 & -9.85 & 4.85 & -22.60 \\
\hline CIM- $446 \times$ CIM-707 & -15.48 & -24.86 & -3.43 & -23.46 & -11.76 & -18.05 & -4.69 & -22.24 \\
\hline CIM-496 × CIM-446 & -5.78 & -12.92 & 11.91 & -16.55 & -1.74 & -5.31 & 10.08 & -23.74 \\
\hline CIM- $496 \times$ CIM- 499 & $14.78^{* *}$ & $9.27^{* *}$ & 19.12 & -6.12 & 13.10 & 4.74 & 12.86 & -5.91 \\
\hline CIM-496 × CIM-506 & -15.10 & -19.04 & -11.73 & -33.11 & -15.28 & -21.45 & -15.35 & -36.78 \\
\hline CIM-496 × CIM-554 & 2.83 & -3.81 & 4.87 & -21.38 & 9.33 & -0.92 & 6.76 & -12.30 \\
\hline CIM-496 × CIM-707 & 4.49 & 0.17 & 9.21 & -9.57 & -3.20 & -6.82 & 0.41 & -18.93 \\
\hline CIM-499 × CIM-446 & -15.74 & -25.56 & -4.33 & -34.65 & -4.59 & -14.63 & -0.71 & -5.71 \\
\hline CIM-499 × CIM-496 & -6.61 & -11.09 & -3.07 & -15.57 & 0.08 & -7.32 & -0.12 & -25.66 \\
\hline CIM-499 × CIM-506 & $18.82^{\star *}$ & $18.40^{\star \star}$ & 17.33 & -14.59 & 13.13 & 12.93 & 4.02 & -15.73 \\
\hline CIM-499 × CIM-554 & $15.49^{\star *}$ & $13.37^{\star \star}$ & 11.73 & -9.90 & $20.63^{\star *}$ & $17.80^{*}$ & 8.17 & -11.90 \\
\hline CIM-499 × CIM-707 & $18.55^{\star \star}$ & $17.69^{\star \star}$ & 17.69 & -9.70 & 9.75 & 5.41 & 5.10 & -15.93 \\
\hline CIM-506 × CIM-446 & 3.65 & -8.29 & 17.87 & -11.76 & 1.67 & -8.92 & 5.93 & -20.49 \\
\hline CIM-506 × CIM-496 & -23.09 & -26.66 & -20.04 & -41.86 & -13.62 & -19.91 & -13.69 & -35.54 \\
\hline CIM-506 × CIM-499 & 0.18 & -0.18 & -1.08 & -23.78 & -1.75 & -1.93 & -9.67 & -21.72 \\
\hline CIM-506 × CIM-554 & $8.93^{* *}$ & $6.56^{\star}$ & 5.60 & -26.97 & 3.79 & 1.22 & -6.76 & -37.15 \\
\hline CIM-506 × CIM-707 & $18.33^{\star \star}$ & $17.69^{\star \star}$ & 17.69 & -12.13 & $23.32^{\star \star}$ & $18.60^{\star *}$ & 18.26 & 2.41 \\
\hline CIM-554 × CIM-446 & 3.72 & -9.83 & 15.88 & -15.86 & -10.01 & -21.16 & -8.30 & -32.77 \\
\hline CIM-554 × CIM-496 & -2.30 & -8.61 & -0.36 & -10.39 & -7.90 & -16.56 & -10.08 & -15.84 \\
\hline CIM-554 × CIM-499 & $5.11^{\star \star}$ & $13.00^{\star *}$ & 11.37 & 0.00 & $19.52^{\star}$ & $16.72^{\star}$ & 7.18 & -10.87 \\
\hline CIM-554 × CIM-506 & 5.21 & 2.91 & 1.99 & -6.15 & 14.55 & 11.71 & 2.90 & -13.53 \\
\hline CIM-554 × CIM-707 & $22.22^{* *}$ & $19.13^{\star *}$ & 19.13 & -6.78 & 4.60 & -1.79 & -2.07 & -19.04 \\
\hline CIM-707 × CIM-446 & -2.84 & -13.62 & 11.01 & -10.61 & -14.60 & -20.69 & -7.76 & -34.11 \\
\hline CIM-707 × CIM-496 & 4.66 & 0.33 & 9.39 & -23.77 & 0.00 & -3.74 & 3.73 & -22.84 \\
\hline CIM-707 × CIM-499 & $8.73^{\star *}$ & $7.94^{\star *}$ & 7.94 & -18.75 & 9.32 & 4.99 & 4.69 & -21.28 \\
\hline CIM-707 × CIM-506 & $15.24^{\star \star}$ & $14.62^{\star \star}$ & 14.62 & -3.64 & 0.95 & -2.91 & -3.20 & -21.95 \\
\hline CIM-707 × CIM-554 & $12.78^{\star \star}$ & $9.93^{* *}$ & 9.93 & -13.49 & 4.29 & -2.08 & -2.37 & -21.01 \\
\hline
\end{tabular}

Check: CIM-473 $=5.54$ Check: CIM-473 $=24.10 . *$ : Significant. 
to enhance the seed cotton yield at end. Highest negative inbreeding depression was noted in CIM-506 $\times$ CIM-496 while lowest negative inbreeding depression was observed in CIM-707 $\times$ CIM-506 having values $-41.86 \%$ and $-3.64 \%$, respectively (Table 3). It has also been suggested that little inbreeding depression exists for $\mathrm{F}_{2}$ and $\mathrm{F}_{3}$ generations and it is possible to screen and select high yielding $\mathrm{F}_{2}$ hybrids [18]. Indication of high inbreeding depression even by having superior heterotic performances was also revealed that high performing hybrids had showed high inbreeding depression. It has elaborated that $\mathrm{F}_{2}$ populations can be used as hybrid cotton if have better performance over their superior parents because $\mathrm{F}_{2}$ crop can easily be managed with increased amount of seed produced by $F_{1}$ plants [19]. Therefore, in cotton the $F_{2}$ populations could be used for hybrid cotton production.

Seeds per boll: Seeds per boll varied from 21.10 (CIM-554) to 28.03 (CIM-446) among parental cultivars and 20.40 (CIM-496 $\times$ CIM-506) to 28.50 $\left(\right.$ CIM-506 $\times$ CIM-707) among $F_{2}$ population (Table 2). Seeds per boll play a vital role in contributing seed cotton yield. Path coefficient analysis showed that seeds per boll had positive effect on yield. Out of $30 \mathrm{~F}_{2}$ hybrids, 18 showed positive mid parent heterosis ranged from $0.00 \%$ (CIM-707 $\times$ CIM-496) to $23.32 \%$ (CIM-506 $\times$ CIM-707), while $09 \mathrm{~F}_{2}$ hybrids performed superior over their parents and showed positive heterobeltiosis ranged from $1.22 \%$ (CIM-506 $\times$ CIM-554) to $18.60 \%$ (CIM-506 $\times$ CIM-707). Rest of $\mathrm{F}_{2}$ population revealed negative heterotic performances for the respective trait. Collectively, $06 \mathrm{~F}_{2}$ hybrids showed significant heterosis for both mid and better parent, respectively. $\mathrm{F}_{2}$ hybrid heterosis in cotton has been reported by several workers and $\mathrm{F}_{2} \mathrm{~s}$ can express at least $50 \%$ of the economic heterosis shown by $\mathrm{F}_{1}$ hybrids, which can lead to cultivar improvement [20] [21] [22]. Moreover, half number of $\mathrm{F}_{2}$ hybrids showed $50 \%$ positive economic heterosis ranged from $0.41 \%(\mathrm{CIM}-496 \times$ CIM-707) to $18.26 \%$ (CIM-506 $\times$ CIM-707). Overall, 60\%, 30\% and 50\% of mid parent, better parent and economic heterosis has been recorded for the said trait (Table 3). It was suggested that little inbreeding depression exists for $\mathrm{F}_{2}$ and $\mathrm{F}_{3}$ generations and it is possible to screen and select high yielding $\mathrm{F}_{2}$ hybrids as already mentioned above. In case of inbreeding depression, only one $\mathrm{F}_{2}$ hybrid (CIM-506 $\times$ CIM-707) performed positively and showed (2.41\%) positive inbreeding depression while rest of $\mathrm{F}_{2}$ population performed well by showing stability even after segregation and revealed negative inbreeding depression ranged from $-5.71 \%$ (CIM-499 × CIM-446) to $-37.15 \%$ (CIM-506 × CIM-554) (Table 3). It was also showed that high performing hybrids showed high inbreeding depression. High inbreeding depression was performed by high performing hybrids. The existence of superior lines in $\mathrm{F}_{2}$ reveals that superior alleles for the trait may have accumulated in the same line. The seeds per ball is a quantitative trait so additive gene action may be involved and those have contributed in the better performance. Results supported the idea that $\mathrm{F}_{2}$ populations could work as a hybrid crop if properly managed and if parents selected on basis of $\mathrm{F}_{2}$ performance, be- 
cause $F_{1}$ hybrids cannot clarify the stability of $F_{2}$ populations [23]. Therefore, such $\mathrm{F}_{2}$ populations would be desirable to use as hybrid cotton to enhance the boll number and eventually seed cotton yield.

Lint\% (GOT): The lint \% (GOT) varied from 32.20 (CIM-707) to 34.80 (CIM-506) among parents and 32.10 (CIM-446 $\times$ CIM-496) to 35.05 (CIM-496 $\times$ CIM-446) among $F_{2}$ population (Table 2). Lint\% after ginning of seed cotton becomes a chief output for cotton breeders because cotton is basically grown for purpose of obtaining fibers. We extract edible oil from cotton seed which serves as a byproduct for people used. Out of $30 \mathrm{~F}_{2}$ cross combinations, 13 cross combinations showed positive mid parent heterosis ranged from $0.32 \%$ (CIM-506 $\times$ CIM-496) to $6.27 \%$ (CIM-496 $\times$ CIM-446). Further, $09 \mathrm{~F}_{2}$ hybrids revealed positive heterobeltiosis ranged from $0.36 \%$ (CIM-707 $\times$ CIM-554) to $4.23 \%$ (CIM$554 \times$ CIM-446), while remaining all $\mathrm{F}_{2}$ population performed heterotically negative for both mid and better parent. Moreover, only $01 \mathrm{~F}_{2}$ hybrid (CIM-496 $\times$ CIM-446) revealed ( $0.68 \%$ ) positive economic heterosis while rest of $F_{2}$ population showed negative economic heterosis. Overall, $43.33 \%, 30 \%$ and $3.33 \%$ of the $\mathrm{F}_{2}$ population showed positive mid parent, better parent and economic heterosis, respectively for lint\% (Table 4). The current findings are accorded with the findings that revealed low lint\% values for heterosis after staple length [24]. In case of inbreeding depression, more than half number of $\mathrm{F}_{2}$ hybrids revealed negative inbreeding depression ranged from $-1.90 \%(\mathrm{CIM}-499 \times \mathrm{CIM}-707)$ to $-12.07 \%$ (CIM-554 $\times$ CIM-707) means $F_{2}$ population has shown stability and performed well after segregation in comparison with the $F_{1}$ generation. The $F_{2}$ hybrids including CIM-446 × CIM-506, CIM-506 $\times$ CIM-707 and CIM-496 $\times$ CIM-446 performed positively by having values of $15.55 \%, 9.76 \%$ and $8.54 \%$, respectively and revealed positive inbreeding depression for the said trait (Table 4). Lower magnitude of inbreeding depression for lint \% and staple length indicated that additive genes were responsible for the expression of these traits [25].

Seed cotton yield per plant: Seed cotton yield varied from 55.74 (CIM-554) to 85.47 (CIM-496) among parental cultivars and 45.94 (CIM-446 × CIM-499) to 92.04 (CIM-506 $\times$ CIM-496) among $\mathrm{F}_{2}$ population (Table 2). Seed cotton yield per plant is a major and very important trait in growing cotton besides lint yield. As seed cotton yield was highly depended on boll plant ${ }^{-1}$ due to presence of close relationship between them [26]. Out of 30 cross combinations, 11 showed positive mid parent heterosis ranged from $0.53 \%$ (CIM-446 × CIM-496) to $30.71 \%$ (CIM-554 $\times$ CIM-499) while only $05 \mathrm{~F}_{2}$ hybrids showed positive heterobeltiosis ranged from $2.23 \%(\mathrm{CIM}-707 \times \mathrm{CIM}-499)$ to $15.41 \%(\mathrm{CIM}-446 \times$ CIM-554). Collectively, $06 \mathrm{~F}_{2}$ hybrids showed significant heterosis for both mid and better parent, respectively. It was observed that significant mid parent heterosis in 13 hybrids and heterobeltiosis in 11 hybrids for seed cotton yield in upland cotton. Seed cotton yield was found with greater variation mostly affected by different yield contributing traits in different previous studies [18]. Moreover, 06 $\mathrm{F}_{2}$ hybrids revealed positive economic heterosis ranged from $0.22 \%$ (CIM-496 $\times$ 
Table 4. Heterosis (MP, BP \& Eco.) and Inbreeding Depression for lint $\%$ and Seed cotton yield plant ${ }^{-1}$ in $\mathrm{F}_{2} \mathrm{~s}_{\text {of }}$ upland cotton.

\begin{tabular}{|c|c|c|c|c|c|c|c|c|}
\hline \multirow{2}{*}{$\mathrm{F}_{2}$ Populations } & \multicolumn{4}{|c|}{ Lint \% (GOT) } & \multicolumn{4}{|c|}{ Seed cotton yield per plant (\%) } \\
\hline & MP (\%) & BP (\%) & Ec. Het (\%) & Inb. Dep. (\%) & MP (\%) & $\mathrm{BP}(\%)$ & Ec. Het (\%) & Inb. Dep. (\%) \\
\hline CIM-446 × CIM-496 & -2.66 & -4.75 & -7.79 & -7.52 & 0.53 & -12.76 & -2.82 & -54.86 \\
\hline CIM-446 × CIM-499 & -1.20 & -3.81 & -5.86 & -1.97 & -33.77 & -39.44 & -40.12 & -45.66 \\
\hline CIM-446 × CIM-506 & -3.01 & -6.56 & -6.57 & 15.55 & -4.70 & -16.79 & -8.62 & -49.95 \\
\hline CIM-446 × CIM-554 & 1.10 & -0.21 & -5.06 & -4.73 & $22.35^{\star *}$ & $15.41^{*}$ & -5.42 & -58.98 \\
\hline CIM-446 × CIM-707 & 1.52 & 1.39 & -6.00 & 0.43 & 7.31 & -0.23 & -4.91 & -50.18 \\
\hline CIM-496 × CIM-446 & 6.27 & 4.04 & 0.68 & 8.54 & 9.2 & -5.24 & 5.57 & -52.91 \\
\hline CIM-496 × CIM-499 & -0.38 & -0.94 & -3.04 & -2.68 & -12.11 & -17.05 & -7.59 & 7.04 \\
\hline CIM-496 × CIM-506 & -0.50 & -2.07 & -2.10 & 3.15 & -27.45 & -27.96 & -19.75 & -27.92 \\
\hline CIM-496 × CIM-554 & 1.65 & 0.77 & -2.44 & -10.13 & 8.90 & -10.04 & 0.22 & -31.85 \\
\hline CIM-496 × CIM-707 & -0.73 & -2.94 & -6.03 & -7.89 & -33.19 & -38.03 & -30.96 & -31.87 \\
\hline CIM-499 × CIM-446 & 1.12 & -1.56 & -3.65 & -4.01 & -13.04 & -20.49 & -21.38 & -19.74 \\
\hline CIM-499 × CIM-496 & -1.00 & -1.56 & -3.65 & -10.13 & -25.75 & -29.93 & -21.94 & -49.33 \\
\hline CIM-499 × CIM-506 & -2.55 & -1.52 & -3.61 & -4.77 & -12.20 & -16.58 & -8.38 & -23.56 \\
\hline CIM-499 × CIM-554 & -2.97 & 1.53 & -0.60 & 3.19 & $12.14^{*}$ & -2.73 & -3.82 & -27.43 \\
\hline CIM-499 × CIM-707 & -4.25 & -0.74 & -0.83 & -1.90 & -0.97 & -2.78 & -3.87 & 37.36 \\
\hline CIM-506 × CIM-446 & -3.90 & -7.41 & -7.44 & 4.01 & -16.05 & -26.70 & -19.50 & -65.40 \\
\hline CIM-506 × CIM-496 & 0.32 & -1.26 & -1.29 & -4.95 & 8.46 & 7.69 & 19.97 & -11.82 \\
\hline CIM-506 × CIM-499 & -3.80 & -4.83 & -4.85 & -5.34 & -8.66 & -13.21 & -4.68 & -40.00 \\
\hline CIM-506 × CIM-554 & 1.00 & -1.44 & -1.47 & 3.06 & -15.00 & -29.39 & -22.45 & -68.83 \\
\hline CIM-506 × CIM-707 & 1.04 & -2.73 & -2.76 & 9.76 & -4.35 & -10.69 & -1.92 & -0.48 \\
\hline CIM-554 × CIM-446 & 5.59 & 4.23 & -0.83 & 3.11 & -9.33 & -14.47 & -29.91 & -68.89 \\
\hline CIM-554 × CIM-496 & -2.15 & 1.27 & -1.95 & 1.70 & -13.73 & -28.74 & -20.61 & -32.30 \\
\hline CIM-554 × CIM-499 & 0.29 & -1.12 & -3.22 & -10.87 & $30.71^{\star *}$ & $13.38^{* *}$ & 12.11 & -23.99 \\
\hline CIM-554 × CIM-506 & -1.08 & -3.47 & -3.50 & -2.47 & 5.96 & -11.97 & -3.32 & -50.97 \\
\hline CIM-554 × CIM-707 & 4.50 & 3.05 & -1.95 & -12.07 & $19.96^{* *}$ & 5.72 & 0.72 & -40.58 \\
\hline CIM-707 × CIM-446 & -3.47 & 3.35 & -4.19 & -2.66 & -11.90 & -18.06 & -21.94 & -50.65 \\
\hline CIM-707 × CIM-496 & -0.27 & -2.49 & -5.60 & 3.69 & -14.30 & -20.51 & -11.44 & -54.44 \\
\hline CIM-707 × CIM-499 & 0.93 & -1.85 & -3.94 & -2.11 & 4.13 & 2.23 & 1.08 & -1.71 \\
\hline CIM-707 × CIM-506 & -0.17 & -3.91 & -3.94 & -4.59 & -10.00 & -15.96 & -7.70 & 1.97 \\
\hline CIM-707 × CIM-554 & 1.77 & 0.36 & -4.51 & 0.00 & -16.87 & -26.73 & -30.20 & -58.89 \\
\hline
\end{tabular}

Check: CIM-473 $=34.81$ Check: CIM-473 $=76.72 .{ }^{*}$ : Significant. 
CIM-554) to $19.97 \%$ (CIM-506 × CIM-496). In case of inbreeding depression, all $\mathrm{F}_{2}$ populations showed negative inbreeding depression except three $\mathrm{F}_{2}$ hybrids. Overall, 36.66\%, $16.66 \%$ and $20 \%$ heterosis was noted for mid parent, better parent and for economic heterosis (Table 4). Out of 30 cross combinations, 27 cross combination revealed negative inbreeding depression means $\mathrm{F}_{2}$ has more stability to perform well after segregation and have great potential to explore it in future to come out with a fruitful results. Maximum inbreeding depression was observed in the cross CIM-554 × CIM-446 (-68.89\%) while minimum inbreeding depression were recorded in CIM-506 $\times$ CIM-707 (-0.48\%). High inbreeding depression has also been observed for the seed cotton yield. Moreover, only three $\mathrm{F}_{2}$ hybrids i.e., CIM-499 $\times$ CIM-707, CIM-496 × CIM-499 and CIM-707 × CIM-506 performed positively by having values of $37.36 \%, 7.04 \%$ and $1.97 \%$, respectively (Table 4 ). $\mathrm{F}_{2}$ hybrids with lower inbreeding depression in yield expressed superior performance over well-adapted cultivars as already mentioned by Meredith. Even after inbreeding depression in $\mathrm{F}_{2} \mathrm{~s}$, presence of some promising population can reveal better performance hence positive selection can provide better opportunity for further improvement.

\section{Conclusions}

The $\mathrm{F}_{2}$ hybrids manifested a remarkable percentage and ranges of mid parent, better parent and economic heterosis having negligible effects of inbreeding depression for majority of the characters of upland cotton. The remarkable heterotic performance for mid parent and better parent was revealed by the $\mathrm{F}_{2}$ population including, CIM-554 × CIM-707, CIM-499 × CIM-506, CIM-499 $\times$ CIM-707, CIM-506 × CIM-707, CIM-499 × CIM-554, CIM-554 × CIM-499, CIM-496 $\times$ CIM-446 and CIM-446 $\times$ CIM-554, respectively while CIM-496 $\times$ CIM-499, CIM-506 × CIM-707, CIM-496 × CIM-446, CIM-506 × CIM-496 and CIM-554 $\times$ CIM-499 were the $\mathrm{F}_{2}$ hybrids which showed the highest positive economic heterosis. Collectively, CIM-499 × CIM-554, CIM-554 × CIM-499, CIM-554 × CIM-707 and CIM-506 × CIM-707 showed superiorly with significant heterosis for yield and yield contributing traits for all parameters except lint\%. Majority of the $\mathrm{F}_{2}$ population did not reveal inbreeding depression meant having superiority over $\mathrm{F}_{1} \mathrm{~s}$ even after segregation which is more desirable for selection of best hybrid cotton. Overall, these parental cultivars and $\mathrm{F}_{2}$ hybrids can be used and studied for further betterment in advanced generations for improvement of seed cotton as they have the capabilities to produce excess yield and production of cotton in future breeding program.

\section{References}

[1] Pareetha, S. and Raveendren, T.S. (2008) Genetic Appraisal of Yield and Fiber Quality Traits in Cotton Using Interspecific $\mathrm{F}_{2}, \mathrm{~F}_{3}$ and $\mathrm{F}_{4}$ Population. Journal of Integrative Plant Biology, 3, 136-142.

[2] Meredith, W.R. (1990) Yield and Fiber Quality Potential for Second Generation 
Cotton Hybrids. Crop Science, 30, 1045-1048.

https://doi.org/10.2135/cropsci1990.0011183X003000050018x

[3] Soomro, A.R. and Kalhoro, A.D. (2000) Hybrid Vigor $\left(\mathrm{F}_{1}\right)$ and Inbreeding Depression $\left(\mathrm{F}_{2}\right)$ for Some Economic Traits in Crosses between Glandless and Glanded Cotton. Pakistan Journal of Biological Sciences, 3, 2013-2015. https://doi.org/10.3923/pjbs.2000.2013.2015

[4] Meredith, W.R. and Bridge, R.R. (1972) Heterosis and Gene Action in Cotton G. hirsutum L. Crop Science, 12, 304-310. https://doi.org/10.2135/cropsci1972.0011183X001200030015x

[5] Meredith, W.R. and Brown, J.S. (1998) Heterosis and Combining Ability of Cottons Originating from Different Regions of United States. Cotton Science, 2, 77-84.

[6] Wu, Y.T., Yin, J.M., Guo, W.Z., Zhu, X.P. and Zhang, T.Z. (2004) Heterosis Performance of Yield and Fiber Quality in $\mathrm{F}_{1}$ and $\mathrm{F}_{2}$ Hybrids in Upland Cotton. Plant Breed, 123, 285-289. https://doi.org/10.1111/j.1439-0523.2004.00990.x

[7] Tang, B., Jenkins, J.N., McCarty, J.C. and Watson, C.E. (1993) $F_{2}$ Hybrids of Host Plant Germplasm and Cotton Cultivars. 1. Heterosis and Combining Ability for Lint Yield and Yield Components. Crop Science, 33, 700-705. https://doi.org/10.2135/cropsci1993.0011183X003300040012x

[8] Natera, J.R.M., Rondon, A., Hernandez, J. and Pinto, J.F.M. (2007) Genetic Studies in Upland Cotton (G. hirsutum L.) and Heterotic Effects. Pakistan Journal of Botany, 39, 385-395.

[9] Steel, R.G.D. and Torrie, J.H. (1980) Principles and Procedures of Statistics, a Biological Approach. 2nd Edition, McGraw Hill, Inc., New York.

[10] Fehr, W.R. (1987) Principles of Cultivar Development. Theory and Technique. Macmillan Pub. Comp. Inc., New York, 115-119.

[11] Fonseca, S.M. (1965) Heterosis, Heterobeltiosis, Diallel Analysis and Gene Action in Crosses of Triticum aestivum L. Ph.D. Thesis, Purdue University, West Lafayette, Indiana.

[12] Wynne, J.C., Emery, D.A. and Rice, P.M. (1970) I. Combining Ability Estimates in Arachis hypogeae L. 11. Field Performance of $\mathrm{F}_{1}$ Hybrids. Crop Science, 10, 713-715. https://doi.org/10.2135/cropsci1970.0011183X001000060036x

[13] Baloch, M.J., Lakho, A.R. and Soomro, A.H. (1993) Heterosis in Interspecific Cotton Hybrids. Pakistan Journal of Botany, 25, 13-20.

[14] Khan, U.Q., Chang, M.A., Malik, A.J. and Hassan, G. (2003) Study of Heterosis in Some Agronomic Traits of Upland Cotton. Sarhad Journal of Agriculture, 19, 369-374.

[15] Percy, R.G., Cantrell, R.G. and Zhang, J. (2006) Genetic Variation for Agronomic and Fiber Properties in an Introgressed Recombinant Inbred Population of Cotton. Crop Science, 46, 1311-1317. https://doi.org/10.2135/cropsci2005.08-0284

[16] Batool, S., Khan, N.U., Makhdoom, K., Bibi, Z., Hassan, G., Marwat, K.B., Farhatullah, Mohammad, F., Raziuddin and Khan, I.A. (2010) Heritability and Genetic Potential of Upland Cotton Genotypes for Morpho-Yield Traits. Pakistan Journal of Botany, 42, 1057-1064.

[17] Soomro, M.H., Markhand, G.S. and Mirbahar, A.A. (2010) Exploring Heterosis for Seed Cotton Yield in Upland Cotton under Different Irrigation Regimes. Pakistan Journal of Botany, 42, 2297-2305.

[18] Yuan, Y.L., Zhang, T.Z., Guo, W.Z., Pan, J.J. and Kohel, R.J. (2001) Heterosis and Gene Action of Boll Weight and Lint Percentage in High Quality Fiber Property 
Varieties in Upland Cotton. Acta Agronomica Sinica, 28, 196-202.

[19] Khan, N.U., Abro, H.K., Kumbhhar, M.B., Hassan, G. and Khan, M. (1999) Exploitation of Heterosis Can Combat Cotton Leaf Curl Virus (CLCuV) Incidence in Cotton (G. hirsutum L). The Pakistan Cottons, 43, 21-33.

[20] Khan, N.U., Abro, H.K., Kumbhar, M.B., Hassan, G. and Mahmood, G. (2000) Study of Heterosis in Upland Cotton-11 Morphology and Yield Traits. The Pakistan Cottons, 44, 13-23.

[21] Xing, C.Z., Yu, S.X., Guo, L.P., Miao, C.D., Feng, W.J., Wang, H.L. and Zhao, Y.L. (2000) Heterosis Performance and Correlation Analysis on Economic Traits of Upland Cotton Hybrid in Different Ecological Environments. Cotton Science, 19, 3-7.

[22] Wei, X.C., Li, Q.Z., Pang, J.Q., Zhang, J., Zhao, J.H. and Wang, L.G. (2002) Heterosis of Pre-Forest Lint Yield of Hybrid between Cultivars or Lines within Upland Cotton (G. hirsutum L.). Cotton Science, 14, 269-272.

[23] Galanopoulou-Sendouca, S. and Roupalias, G. (1999) Performance of Cotton $F_{1}$ Hybrids and Its Relation to the Mean Yield of Advanced Bulk Generations. European Journal of Agronomy, 11, 53-62. https://doi.org/10.1016/S1161-0301(99)00018-0

[24] Khan, N.U., Hassan, G., Kumbhar, M.B., Kang, S., Khan, I., Parveen, A., Aiman, U. and Saeed, M. (2007) Heterosis and Inbreeding Depression and Mean Performance in Segregating Generations in Upland Cotton. European Journal of Scientific Research, 17, 531-546.

[25] Khan, N.U., Hassan, G., Marwat, K.B., Farhatullah, Batool, S., Makhdoom, K., Khan, I., Khan, I.A. and Ahmed, W. (2009) Genetics Variability and Heritability in Upland Cotton. Pakistan Journal of Botany, 41, 1695-1705.

[26] Babar, S.B., Soomro, A.R., Anjum, R. and Kalawar, M.S. (2001) Estimation of Heterosis, Heterobeltiosis and Economic Heterosis in Upland Cotton (G. hirsutum L). Pakistan Journal of Biological Sciences, 4, 518-520.

https://doi.org/10.3923/pjbs.2001.518.520 